\title{
Morphofunctional Characteristics of Pulmonary Surfactant System and Its Effect on Immune Cells in Influenza A (H1N1) Pathogenesis
}

\author{
A. V. Kovner*, 0. V. Potapova, V. A. Shkurupy, A. M. Shestopalov \\ Federal State Budgetary Scientific Institution Research Institute of Experimental and Clinical Medicine, \\ Novosibirsk, Russia \\ Email: ${ }^{*}$ anya.kovner@gmail.com
}

Received 26 August 2015; accepted 1 January 2016; published 6 January 2016

Copyright (C) 2016 by authors and Scientific Research Publishing Inc.

This work is licensed under the Creative Commons Attribution International License (CC BY).

http://creativecommons.org/licenses/by/4.0/

(c) () Open Access

\section{Abstract}

There is an annual increase of influenza-related SARI cases in winter months. Despite the high relevance of this problem, influenza pathogenesis and the role of surfactant system and its SP-A (surfactant protein A) enzyme in antiviral defense remain poorly understood. SP-A activates macrophage M1 polarization and triggers an antiviral response due to the activation of T-cells and dendritic cells. Therefore, surfactant system is an important element of infection protection and a promising therapeutic target.

\section{Keywords}

Influenza A (H1N1) Virus, Pulmonary Surfactant system, SP-A, M1/M2 Macrophages, Antiviral Defense

\section{Introduction}

Respiratory tract is constantly exposed to various infectious agents. Influenza A virus infection is one of the most common lung infections worldwide that affects the upper and lower respiratory tract [1]. There are 3 types of seasonal influenza viruses-A, B and C. Type A influenza viruses are further classified into subtypes according to the combinations of various virus surface proteins. Among many subtypes of influenza A viruses, influenza A (H1N1) and A (H3N2) subtypes are currently circulating among humans [2]. Only three HA subtypes

${ }^{*}$ Corresponding author.

How to cite this paper: Kovner, A.V., Potapova, O.V., Shkurupy, V.A. and Shestopalov, A.M. (2016) Morphofunctional Characteristics of Pulmonary Surfactant System and Its Effect on Immune Cells in Influenza A (H1N1) Pathogenesis. Open Journal of Pathology, 5, 1-7. http://dx.doi.org/10.4236/ojpathology.2016.61001 
of influenza A viruses (H1N1, H2N2, and H3N2) have caused pandemics in humans in the past century. Thus, these may be the only subtypes that can establish lineages in humans [3].

Yearly influenza epidemics can seriously affect all populations, but the highest risk of complications occur among children younger than age 2 years old, adults aged 65 years or older, pregnant women, and people of any age with certain medical conditions, such as chronic heart, lung, kidney, liver, blood or metabolic diseases (such as diabetes), or weakened immune systems [2].

In human airways influenza replicates in type I [4] and, to a greater extent, type II pneumocytes [5] since these epithelial cells have both SA $\alpha 2,3$-gal and SA $\alpha 2,6$-gal receptors on the surface [6]. The immune response to influenza $\mathrm{A}$ virus is mediated by virus-specific T-lymphocytes and antibodies. Cytotoxic T-lymphocytes are involved in virus elimination through direct cytolysis of infected cells [7]. Influenza A virus infection is associated with neutrophil and monocyte genetic damages impairing their chemotactic, oxidative and bacterial functions [8].

Synthesis of surfactant lining the alveolar septum and consisting mainly (90\%) of lipids and sulfated glycosaminoglycans as well as of apoproteins (surfactant proteins, SP) (10\%) is one of the main functions of type II pneumocytes. There are four main types of surfactant proteins: SP-A, -B, -C, -D. SP-A and SP-D belong to a family of collectins which can bind to microbial cell wall and thereby facilitate opsonization and phagocytosis [9]. Anti-infectious action of surfactant proteins is also associated with their ability to attach infectious agents to membrane surface of macrophages and neutrophils. For instance, free collagen tails of SP-A T-terminal domain interact with macrophage and neutrophil receptors and induce pahgocytosis in the presence of $\mathrm{Ca}^{2+}[10]$. Moreover, pulmonary surfactant is an important link between cell and antibody immune response and surfactant proteins are the first line of defense [11] [12]. SP-A (surfactant protein A) is the most important protein with diverse protective effects, which can be divided into several groups:

1) activation of infectious agent fixation on macrophage membrane and phagocytosis [13];

2) immunomodulatory induction of both pro- and anti-inflammatory activity [14];

3) inhibition of differentiation of dendritic cells, which are an important link between non-specific and specific immune protection [15];

4) macrophage polarization toward M1 phenotype expressing NO-synthase protein, which metabolizes arginine into nitric oxide (NO) and citrulline [16].

However, the role of SP-A in influenza pathology is not adequately addressed in modern literature. We therefore aimed at examining the morphofunctional characteristics of surfactant system and its role in antiviral response. Studies in that field can form the basis of the development of new drugs for influenza including respiratory drugs which affect surfactant system and therefore have an immunomodulatory effect.

\section{Materials and Methods}

The study was carried out on 2-month-old white outbred male mice ( $n=90 ; 20-25 \mathrm{~g})$ from animal nursery of Center of Virology and Biotechnology VECTOR. Seventy mice were intranasally infected with $1 \mathrm{MLD}_{50}$ of A/Tomsk/13/2010 (H1N1) virus, isolated from human lung during seasonal influenza epidemics of 2010 and adapted to mice by six passages. Control group included 20 intact animals.

The animals were kept under standard vivarium conditions with free access to water and food. Biological material for the study was collected in accordance with Helsinki Declaration (1964) and this study was approved by Animal Ethics Committee at the Research Institute of Experimental and Clinical Medicine and carried out in accordance with institutional guidelines.

Lung specimens for histological and immunohistochemical (IHC) study were collected on days 1, 3, 6, 10, 14, 21, and 30 after infection. Animals were sacrificed by cervical dislocation under ether narcosis.

Lung specimens were fixed in 10\% water solution of neutral formalin and dehydrated in HISTOMIX paraffin (BioVitrum). Sections ( 3 - $4 \mu$ ) for histological (hematoxylin-eosin staining) IHC studies were sliced on HM 355S Automatic Microtome (Thermo Scientific) and treated with primary specific antibodies: CD68 (Diagnostic BioSystems), CD-1 $\alpha$ (Diagnostic BioSystems), Arginase (ThermoScientific), Surfactant Apoprotein A (BioCareMedical), TNF- $\alpha$ (Diagnostic BioSystems), iNOS (Spring). Conventionally pre-dewaxed samples from naive mice were used as controls.

In order to perform the immunohistochemical investigation, $3 \mu \mathrm{m}$ lung sections were dewaxed, dehydrated, epitope-retrieved in citrate buffer solution in $700 \mathrm{~W}$ microwave oven during 20 - 35 minutes. Endogenous pe- 
roxidase was being blocked for 10 minutes after double wash in phosphate buffer solution (PBS). The time of exposition to primary antibodies at $37^{\circ} \mathrm{C}$ was $30-45$ minutes. Sections were incubated with HRP-conjugate and DAB substrate and then stained with Mayer's hematoxylin. Sections were dehydrated using ethanols with growing concentrations and xylol mounted with synthetic mounting media "Bio Mount" (BioVitrum, Russia) and placed under cover glasses.

Histological analysis of samples was performed using AxioImager A1 microscope with an AxioCam MRc photocamera (Carl Zeiss). Morphometry study was carried out in a 100 point closed test system with an area of $3.52 \times 10^{4} \mu^{2}$ (to determine numerical densities (Nai) and volume densities (Vv)) and using AxioVision 4.12 software [17]. The means were calculated using Statistica 6 software. The significance of differences in compared means was evaluated by Student's $t$ test. The differences were considered significant at $p<0.05$. Pierson analysis of correlations was carried out.

\section{Results}

Like all known influenza A viruses, Influenza A (H1N1) is pneumotropic and efficiently replicates in respiratory system causing disease with severe lung damage in mammals and particularly in humans [18] [19]. IHC analysis of mice samples demonstrated the presence of virus in alveolar epithelium and lung macrophages 1 day after infection (Figure 1). Positive reaction in cell cytoplasm is an indication of virus in lung tissues in the early stages of disease (Figure 2).

Influenza A virus induces several types of immune response in lungs. As the first line of defense against multiple infectious agents, alveolar macrophages play a key role in innate response. Macrophages can polarize to M1 with proinflammatory response activation and/or to M2 with the secretion of anti-inflammatory cytokines (arginase, in particular) [20]. Surfactant protein SP-A is one of the factors that controls the M1 polarization. SP-A increases macrophage recruitment, phagocytic and secretory activity, including the production of NOsynthases [21] [22] (Figure 3).

The total number of pulmonary macrophages peaked on $3^{\text {rd }}$ day after infection (with 5.2-times higher peak than in control group) (Table 1 ).

Activation peak on the $30^{\text {th }}$ day probably correlates with an increased number of macrophages expressing the antigen of influenza A virus (Figure 1). The number of alternatively activated macrophages (M2) expressing arginase peaked (at least $30 \%$ higher than in subsequent periods) on the $1^{\text {st }}$ and $3^{\text {rd }}$ days after infection and again grew by $40 \%$ to the $30^{\text {th }}$ day (Table 1). The number of M2 macrophages in infected mice was much higher than in intact animals throughout the experiment (Table 1).

The number of pneumocytes expressing SP-A was the highest on days 3 and 6 after infection (Figure 4). However, the number of SP-A + pneumocytes remained high throughout the experiment and exceeded the control values by 4.8 times on average (Table 1 ).

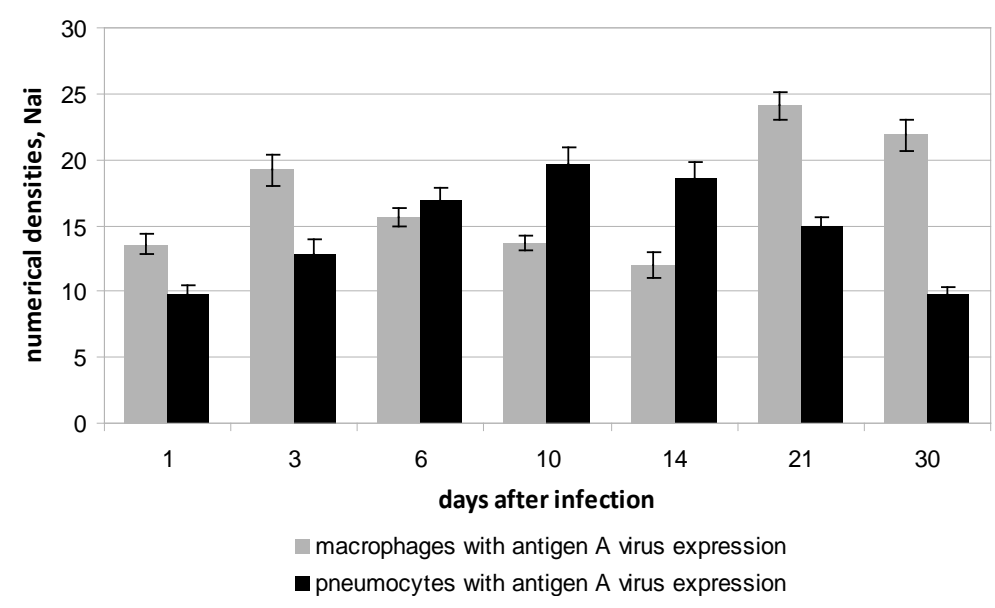

Figure 1. Numerical densities of pulmonary macrophages and pneumocytes expressing influenza A virus antigen in mice lungs infected with $\mathrm{A} / \mathrm{Tomsk}$ / 13/2010 (H1N1) virus. 


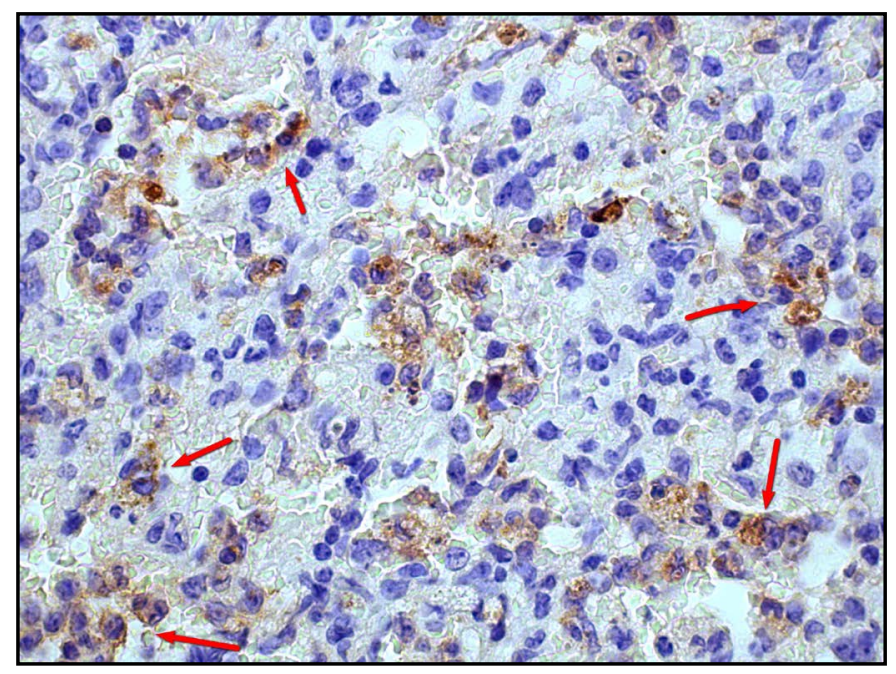

Figure 2. Influenza A virus antigen expression by macrophages of mice lung infected with A/Tomsk/13/2010 (H1N1) virus. Third day after infection. Immunohistochemical analysis. Magnification $\times 400$.
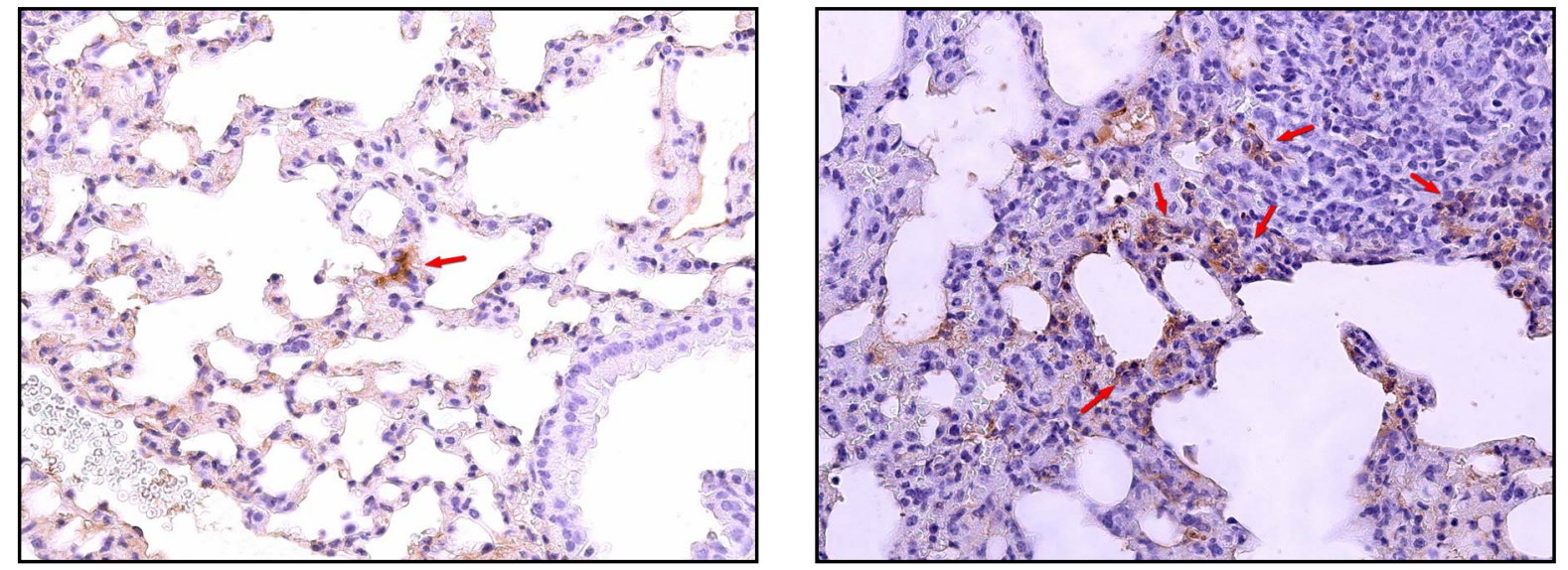

Figure 3. Lung fragment of intact mice (infect) and mice infected with A/Tomsk/13/2010 (H1N1) virus. iNOS expression by mouse macrophages (shown by arrows). Third day after infection. Immunohistochemical analysis. Magnification $\times 200$.
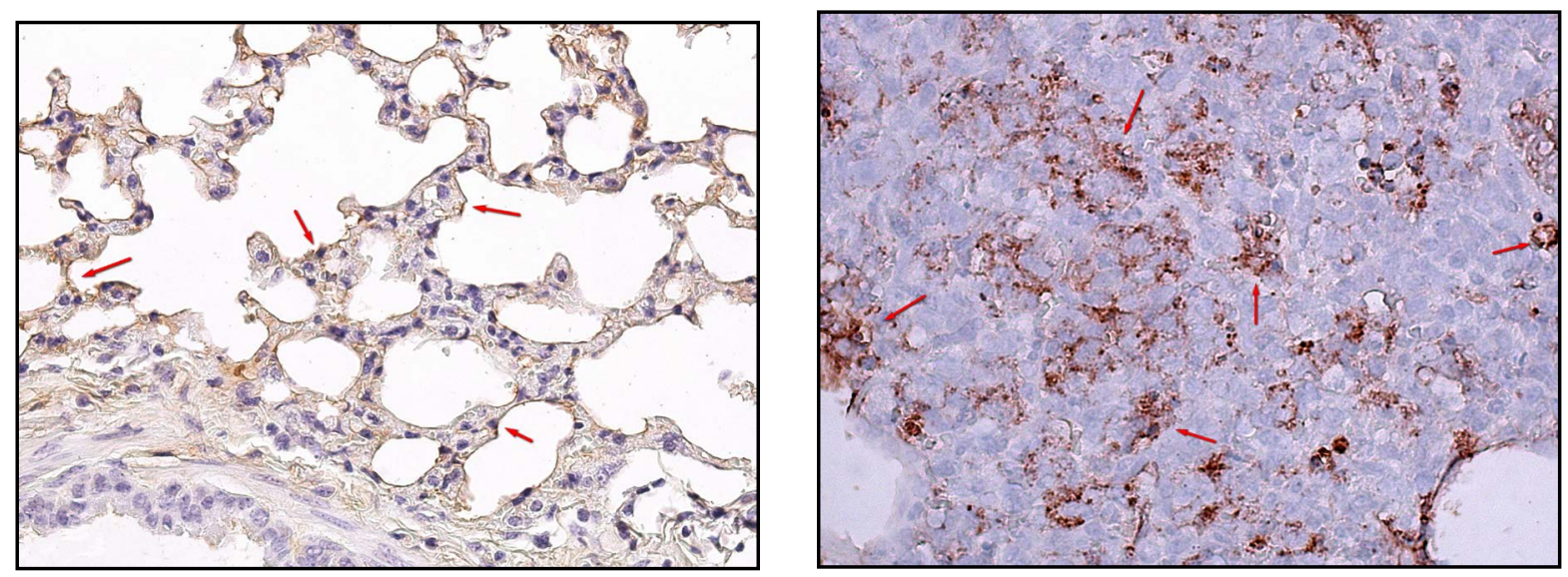

Figure 4. Lung fragment of intact mice (right) and mice infected with A/Tomsk/13/2010 (H1N1) virus (left). SP-A expression by pneumocytes of mice (shown by arrows). First day after infection. Immunohistochemical analysis. Magnification $\times 400$. 
Table 1. Numerical densities of mouse pulmonary macrophages and pneumocytes after infection with A/Tomsk/13/2010 (H1N1) virus $(\mathrm{M} \pm \mathrm{m})$.

\begin{tabular}{|c|c|c|c|c|}
\hline $\begin{array}{l}\text { Days after } \\
\text { infection }\end{array}$ & $\begin{array}{c}\text { Total number of } \\
\text { macrophages (CD68+) }\end{array}$ & $\begin{array}{c}\text { Number of alternatively activated } \\
\text { macrophages (M2) (arginase+) }\end{array}$ & $\begin{array}{c}\text { Number of classically activated } \\
\text { macrophages (M1) (iNOS+) }\end{array}$ & $\begin{array}{c}\text { Number of type } \\
\text { II pneumocytes (SP-A+) }\end{array}$ \\
\hline 1 & $44.5 \pm 0.98^{\mathrm{a}}$ & $17.9 \pm 1.82^{\mathrm{a}}$ & $21.5 \pm 1.7$ & $23.1 \pm 1.61^{\mathrm{a}}$ \\
\hline 3 & $52.8 \pm 1.36^{\mathrm{ab}}$ & $17.5 \pm 1.35^{\mathrm{a}}$ & $26.1 \pm 1.5$ & $26.2 \pm 1.39^{\mathrm{a}}$ \\
\hline 6 & $39.2 \pm 1.2^{\mathrm{ab}}$ & $11.6 \pm 1.45^{\mathrm{ab}}$ & $18.2 \pm 1.4$ & $21.3 \pm 0.93^{\mathrm{ab}}$ \\
\hline 10 & $38.5 \pm 1.84^{\mathrm{a}}$ & $7.8 \pm 0.89^{\mathrm{ab}}$ & $21.2 \pm 0.9$ & $22.6 \pm 0.95^{\mathrm{a}}$ \\
\hline 14 & $38.3 \pm 1.01^{\mathrm{a}}$ & $7.7 \pm 0.60^{\mathrm{a}}$ & $15.5 \pm 2.4$ & $18.9 \pm 1.24^{\mathrm{ab}}$ \\
\hline 21 & $38.1 \pm 1.52^{\mathrm{a}}$ & $9.4 \pm 1.56^{\mathrm{a}}$ & $19.9 \pm 1$ & $26.1 \pm 0.89^{\mathrm{ab}}$ \\
\hline 30 & $39.9 \pm 1.08^{\mathrm{ab}}$ & $13.1 \pm 1.62^{\mathrm{ab}}$ & $24.8 \pm 1.7$ & $24.6 \pm 1.33^{\mathrm{a}}$ \\
\hline control & $10.1 \pm 0.96$ & $1.3 \pm 0.34$ & $3.64 \pm 0.4$ & $4.8 \pm 0.65$ \\
\hline
\end{tabular}

${ }^{\mathrm{a}}$ Significance of differences between experimental and control groups; ${ }^{\mathrm{b}}$ Significance of differences between current and previous experimental periods.

The coefficient of correlation (r) between surfactant protein SP-A expression and the total number of CD68 + macrophages was +0.927 , and the coefficient of correlation between surfactant protein SP-A expression and macrophage iNOS+ expression was +0.799 .

Surfactant system affects immune cells during viral infection. Dendritic cells play an important role in maintaining the proinflammatory response [23]. Their number started to grow since as early as $1^{\text {st }}$ day of the experiment, exceeding control value by 4.9 times on average (Table 2). Among other effects, surfactant system slows down the differentiation of dendritic cells thereby increasing the production of proinflammatory cytokines [17].

There was a strong correlation between SP-A and CD1 $\alpha+$ dendritic cells with $r=+0.732$. Growing number of $\mathrm{CD} 1 \alpha+$ cells, induced by proinflammatory cytokine expression, supported M1 macrophage population.

The role of surfactant system (SP-A) in T-cell-component of immune system was also studied. The number of cytotoxic and cytolytic T cells was the same in control animals (Table 2), and there was an average $44 \%$ predomination of cytotoxic lymphocytes over cytolytic lymphocytes in mice infected with influenza A (H1N1) throughout the experiment (Table 2).

There was a strong correlation between pneumocytes expressing SP-A and CD4+ and CD8+ T cells with $\mathrm{r}=$ +0.797 and $r=+0.793$, respectively. Surfactant-protein-stimulated increase in lymphocytes of both types in response to viral infection provided the elimination of virus through direct cytolysis of infected cells.

\section{Discussion}

Immunohistochemical analysis has shown that seasonal influenza viruses can replicate in lower airways like H5N1 viruses and activate mononuclear phagocyte system including alveolar macrophages [24]. M1-activated macrophages predominated throughout the study including the $14^{\text {th }}$ and the $30^{\text {th }}$ days after infection during convalescence period. That is primarily due to prolonged persistence of influenza in cells of infected mice lungs as indirectly demonstrated by high numerical densities of macrophages and type II pneumocytes expressing influenza A antigen throughout the study. However, the analysis of correlation between the number of M1 macrophages and SP-A-immunopositive pneumocytes has shown that type II pneumocytes and/or surfactant proteins take part in macrophage M1 polarization. It was also found that they directly contributed to the functional activation of hyperplasia of T-helper cells and CD1 $\alpha$ dendritic cells. It can be assumed that seasonal influenza infection in mammals supports the intensity of cell immunity in all periods of the study including convalescence period. The immune response eliminates the pathogen, provides prolonged secretion of proinflammatory cytokines (TNF- $\alpha$ ), inducible NO-synthase and thereby leads to the secondary alteration of lung tissue. Thus, surfactant system in one of the elements is to activate cell immunity against influenza including M1 activation and to support hyperergic reactions in lung tissue. This should be taken into account while choosing new methods and drugs for ARI treatment and prevention. The drugs should have immunomodulatory effect and decrease the proinflammatory activity of immune cells. 
Table 2. Numerical densities of mouse pulmonary immune cells after infection with A/Tomsk/13/2010 (H1N1) virus (M \pm $\mathrm{m})$.

\begin{tabular}{|c|c|c|c|}
\hline Days after infection & CD1 $\alpha+$ cells & CD-4 $4^{+}$T-lymphocytes & CD-8 ${ }^{+}$T-lymphocytes \\
\hline 1 & $3.4 \pm 0.45^{\mathrm{a}}$ & $14.6 \pm 0.73^{\mathrm{a}}$ & $10.6 \pm 0.93^{\mathrm{a}}$ \\
\hline 3 & $5 \pm 0.54^{\mathrm{ab}}$ & $15.5 \pm 0.69^{\mathrm{a}}$ & $12.2 \pm 1.63^{\mathrm{a}}$ \\
\hline 6 & $6.8 \pm 0.47^{\mathrm{ab}}$ & $20.9 \pm 1.33^{\mathrm{ab}}$ & $17.6 \pm 2.08^{\mathrm{ab}}$ \\
\hline 10 & $7.1 \pm 0.63^{\mathrm{a}}$ & $14.4 \pm 0.89^{\mathrm{ab}}$ & $13.4 \pm 0.59^{\mathrm{ab}}$ \\
\hline 14 & $5.3 \pm 0.51^{\mathrm{ab}}$ & $19.4 \pm 0.77^{\mathrm{ab}}$ & $13.4 \pm 1.02^{\mathrm{a}}$ \\
\hline 21 & $8.5 \pm 0.65^{\mathrm{ab}}$ & $24.8 \pm 0.99^{\mathrm{ab}}$ & $18.6 \pm 1.23^{\mathrm{ab}}$ \\
\hline 30 & $5.5 \pm 0.71^{\mathrm{ab}}$ & $19.5 \pm 1.43^{\mathrm{ab}}$ & $17.2 \pm 0.74^{\mathrm{a}}$ \\
\hline control & $1.2 \pm 0.31$ & $3.3 \pm 0.37$ & $3.7 \pm 0.25$ \\
\hline
\end{tabular}

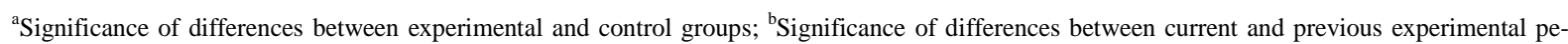
riods.

\section{Conclusion}

Thus, surfactant system is involved in both types of immune response (cellular and antibody) and boosts body resistance to seasonal influenza A (H1N1) virus. M1 activation of macrophages predominates. Stimulation of this process can be another therapeutic target for the treatment of influenza caused by influenza A virus.

\section{Conflict of Interest}

The authors declare no conflict of interest.

\section{References}

[1] Fukuyama, S. and Kawaoka, Y. (2011) The Pathogenesis of Influenza Virus Infections: The Contributions of Virus and Host Factors. Current Opinion in Immunology, 23, 481-486. http://dx.doi.org/10.1016/j.coi.2011.07.016

[2] http://www.who.int/mediacentre/factsheets/fs211/en/

[3] Webster, R.G. and Govorkova, E.A. (2014) Continuing Challenges in Influenza. Annals of the New York Academy of Sciences, 1323, 115-139. http://dx.doi.org/10.1111/nyas.12462

[4] Sirinonthanawech, N., Uiprasertkul, M., Suptawiwat, O. and Auewarakul, P. (2011) Viral Load of the Highly Pathogenic Avian Influenza H5N1 Virus in Infected Human Tissues. Journal of Medical Virology, 83, 1418-1423. http://dx.doi.org/10.1002/jmv.22146

[5] Weinheimer, V.K., Becher, A., Tönnies, M., Holland, G., Knepper, J., Bauer, T.T., Schneider, P., Neudecker, J., Rückert, J.C., Szymanski, K., Temmesfeld-Wollbrueck, B., Gruber, A.D., Bannert, N., Suttorp, N., Hippenstiel, S., Wolff, T. and Hocke, A.C. (2012) Influenza A Viruses Target Type II Pneumocytes in the Human Lung. The Journal of Infectious Diseases, 206, 1685-1694. http://dx.doi.org/10.1093/infdis/jis455

[6] Thongratsakul, S., Suzuki, Y., Hiramatsu, H., Sakpuaram, T., Sirinarumitr, T., Poolkhet, C., Moonjit, P., Yodsheewan, R. and Songserm, T. (2010) Avian and Human Influenza A Virus Receptors in Trachea and Lung of Animals. Asian Pacific Journal of Allergy and Immunology, 28, 294-301.

[7] Zens, K.D. and Farber, D.L. (2015) Memory $\mathrm{CD}_{4} \mathrm{~T}$ Cells in Influenza. Current Topics in Microbiology and Immunology, 386, 399-421. http://dx.doi.org/10.1007/82_2014_401

[8] Murray, P.J. and Wynn, T.A. (2011) Protective and Pathogenic Functions of Macrophage Subsets. Nature Reviews Immunology, 11, 723-737. http://dx.doi.org/10.1038/nri3073

[9] Zhang, L.N., Sun, J.P., Xue, X.Y. and Wang, J.X. (2013) Exogenous Pulmonary Surfactant for Acute Respiratory Distress Syndrome in Adults: A Systematic Review and Meta-Analysis. Experimental and Therapeutic Medicine, 5, 237-242.

[10] LeVine, A.M., Hartshorn, K., Elliott, J., Whitsett, J. and Korfhagen, T. (2002) Absence of SP-A Modulates Innate and Adaptive Defense Responses to Pulmonary Influenza Infection. American Journal of Physiology—Lung Cellular and Molecular Physiology, 282, L563-L572. http://dx.doi.org/10.1152/ajplung.00280.2001 
[11] Possmayer, F. (1988) A Proposed Nomenclature for Pulmonary Surfactant-Associated Proteins. American Review of Respiratory Disease, 138, 990-998. http://dx.doi.org/10.1164/ajrccm/138.4.990

[12] Bourbon, J.R. (1995) Development of the Surfactant System. Pediatric Pulmonology, 19, 94-95. http://dx.doi.org/10.1002/ppul.1950191146

[13] Sender, V., Moulakakis, C. and Stamme, C. (2011) Pulmonary Surfactant Protein A Enhances Endolysosomal Trafficking in Alveolar Macrophages through Regulation of Rab7. The Journal of Immunology, 186, 2397-2411. http://dx.doi.org/10.4049/jimmunol.1002446

[14] Hartshorn, K.L. (2010) Role of Surfactant Protein A and D (SP-A and SP-D) in Human Antiviral Host Defense. Frontiers in Bioscience (Scholar Edition), 2, 527-546.

[15] Nayak, A., Dodagatta-Marri, E., Tsolaki, A.G. and Kishore, U. (2012) An Insight into the Diverse Roles of Surfactant Proteins, SP-A and SP-D in Innate and Adaptive Immunity. Frontiers in Immunology, 3, 131. http://dx.doi.org/10.3389/fimmu.2012.00131

[16] Rath, M., Müller, I., Kropf, P., Closs, E.I. and Munder, M. (2014) Metabolism via Arginase or Nitric Oxide Synthase: Two Competing Arginine Pathways in Macrophages. Frontiers in Immunology, 5, 532. http://dx.doi.org/10.3389/fimmu.2014.00532

[17] Baak, J.P.A. and Oort, J. (1983) A Manual of Morphometry in Diagnostic Pathology. Springer, Berlin. http://dx.doi.org/10.1007/978-3-642-74823-3

[18] Kovner, A.V., Anikina, A.G., Potapova, O.V., Sharkova, T.V., Cherdanceva, L.A., Shkurupy, V.A. and Shestopalov, A.M. (2012) Structural and Functional Changes in Pulmonary Macrophages and Lungs of Mice Infected with Influenza Virus A/H5N1 A/Goose/Krasnoozerskoye/627/05. Bulletin of Experimental Biology and Medicine, 153, 229-232. http://dx.doi.org/10.1007/s10517-012-1683-y

[19] Jiang, P., Zhou, N., Chen, X., Zhao, X., Li, D., Wang, F., Bi, L. and Zhang, D. (2015) Integrative Analysis of Differentially Expressed MicroRNAs of Pulmonary Alveolar Macrophages from Piglets during H1N1 Swine Influenza A Virus Infection. Scientific Reports, 5, Article No. 8167. http://dx.doi.org/10.1038/srep08167

[20] Mills, C.D. (2012) M1 and M2 Macrophages: Oracles of Health and Disease. Critical Reviews in Immunology, 32, 463-488.

[21] Mitsuhashi, A., Goto, H., Kuramoto, T., Tabata, S., Yukishige, S., Abe, S., Hanibuchi, M., Kakiuchi, S., Saijo, A., Aono, Y., Uehara, H., Yano, S., Ledford, J.G., Sone, S. and Nishioka, Y. (2013) Surfactant Protein A Suppresses Lung Cancer Progression by Regulating the Polarization of Tumor-Associated Macrophages. The American Journal of Pathology, 182, 1843-1853. http://dx.doi.org/10.1016/j.ajpath.2013.01.030

[22] Murray, P.J., Allen, J.E., Biswas, S.K., Fisher, E.A., Gilroy, D.W., Goerdt, S., Gordon, S., Hamilton, J.A., Ivashkiv, L.B., Lawrence, T., Locati, M., Mantovani, A., Martinez, F.O., Mege, J.L., Mosser, D.M., Natoli, G., Saeij, J.P., Schultze, J.L., Shirey, K.A., Sica, A., Suttles, J., Udalova, I., van Ginderachter, J.A., Vogel, S.N. and Wynn, T.A. (2014) Macrophage Activation and Polarization: Nomenclature and Experimental Guidelines. Immunity, 41, 14-20. http://dx.doi.org/10.1016/j.immuni.2014.06.008

[23] Upham, J.W. (2003) The Role of Dendritic Cells in Immune Regulation and Allergic Airway Inflammation. Respirology, 8, 140-148. http://dx.doi.org/10.1046/j.1440-1843.2003.00465.x

[24] Kovner, A.V., Potapova, O.V., Shkurupy, V.A. and Shestopalov, A.M. (2013) Morphofunctional Status and the Role of Mononuclear Phagocyte System Lung Compartment in the Pathogenesis of Influenza A (H5N1) in Mammals. Advances in Bioscience and Biotechnology, 4, 979-985. http://dx.doi.org/10.4236/abb.2013.411130 